\title{
Lighting Design for Psychophysical Wellbeing: Tools and Investigation Methods
}

\author{
Gianfranco Cellai ${ }^{1}$, Simone Secchi ${ }^{2}$, Sveva Mazza de' Piccioli ${ }^{2}$ \\ ${ }^{1}$ Department of Engineering, University of Florence, Italy \\ ${ }^{2}$ Department of Architecture, University of Florence, Italy
}

\begin{abstract}
Quality of light in living environments affects users' performance, mood and behaviour. This research is aimed to assess, through an experimental approach, quality of lighting environment and well-being experienced inside buildings of School of Architecture in Florence and has involved 187 students. This trial consists of two stages, one objective and one subjective analysis: the aim is to compare results obtained from lighting measurements taken in classrooms with responses gathered from questionnaires submitted to students. This study proposes therefore a new assessment methodology for lighting comfort in learning environments.
\end{abstract}

\section{Introduction}

International scientific studies confirm that there is a close connection between architectural environment quality (including natural and artificial lighting) and users wellbeing: for instance, sub-optimal lighting conditions in schools cause fatigue, lack of attention and have negative effects on students' performance.

Over the past 25 years, biological effects of light have been deeply investigated under biological and medical research, pointing out existing links between light quality and people performance and health (Baron et al. 1991) (Pechacek, 2008). Moreover, it was found that effects of a good lighting system go beyond regular visual effects (Králiková et al., 2016); biological effects of light produce benefits on health, wellbeing, awareness and on sleep quality as well (Ödemis et al., 2011).

One of the most important outcomes, according to many researchers, is that quality of light is not just related to quantity, but it heavily depends on psychological and behavioural elements (Veicht, 2000-2013; Van Bomme, et al., 2004).

John Flynn (1992) played a pioneering role in pointing out this fundamental issue, in cooperation with other coworkers: their studies suggest that lighting environment conditions can affect users' mood. Among most important researchers, Boyce (2004-2013) as well includes visual comfort and relaxation in good-lighting factors.

Meaningful results concern how specific hormones, such as melanopsin, influence circadian rhythm in human clock and other important hormones.
In addition, new retinal ganglion photoreceptors cells regulating perception of biological effects, discovered by David Berson (2002), represent a fundamental finding in this research field.

Brainard (1997-2001) as a consequence of similar results, suggests new approaches to lighting design, in order to arouse both visual and circadian effects of light.

Also, lighting effects related to learning environment were explored, mostly in recent times, focusing on connection between artificial light features and students' cognitive skills, mood and behaviour. (Castilla et al., 2017-2018).

Aspects of visual quality in lighting projects, such as lighting level, spatial distribution of light and colour rendering index (CRI), must be extended if we want to accomplish lighting projects that provide more benefits for users. In addition, it is well known that lighting colour, in relation to environment colour and to lighting contrast level, affects emotionally moods and space perception. Even a good-quality lighting colour helps improving performances, comfort and users' well-being (Kay et al., 2015).

Scientific research under lighting design offers valuable suggestions for survey methodologies to be implemented in different contexts. DENERG (Energy Department) and LAMSA (Analysis and Modelling Laboratory for Environmental Systems) at Torino Polytechnic promoted for years researches on lighting quality evaluation and wellness perception in different architectural environments (Shahrom, 2015), through practical experimental methods on field. Researchers aim to build up guidelines for lighting projects in relation to surrounding features and space perception (Khademagha et al., 2016).

Based on research reviews and considering current legislation parameters (EN 12464-1) the proposed survey methodology consists in a stage of objective analysis, including computer simulations through software DiaLux Evo®(2016), direct measurements and comparison with minimum standards, alongside with subjective analysis, covering a questionnaire for the students. The purpose is to explore how people who daily attend learning environment feels about lighting effects, and to compare gained results with similar researches' outcomes (Marty et al., 2003).

The final aim is to gather information and find valuable solutions in order to carry out high-quality lighting 
projects. Students from School of Architecture in Florence were chosen as subjects of the research, in order first to assess their satisfaction with existing lighting system in school environment where the computer monitor is observed for several hours; then, in order to see how future architects should take care of artificial lighting implications.

School is divided in two different seats: a building partially refurbished, called Santa Teresa, with some new classrooms (which we'll refer to as building A), and a historical not refurbished building, called Santa Verdiana (which we'll call building B). Students from three-years undergraduate and master's' degree usually attend building $\mathrm{A}$, while students enrolled at five-years degree usually attend courses in building B.

\section{Methods}

This trial comes from similar experiences previously outlined (Ödemis et al., 2011; Castilla et al., 2017-2018; Shahrom, 2015); it relates to learning environment comprising different classrooms distinguished by shape and location, with features summarized in Figure 4, in which different activities are carried out (frontal classes, studio classes and more) during many hours from morning to late afternoon.

During subjective analysis stage, students were asked to undergo an individual multiple-choice assessment questionnaire, drawn up in order to investigate users' perception of a daily-experienced environment. The questionnaire is composed by 35 questions, and structured as follows:

1. Questions 1-9: subjects' daily habits. Questions concerned subject age and gender, amount of days and hours he/she spends inside school building, and any visual disorder he/she is affected by, in order to investigate students' background.

2. Questions 10-16: local environment quality evaluation, specifically referring to classroom conditions perceived while filling the questionnaire - therefore students are also asked to indicate date, time and classroom in which they are answering questions.

3. Questions 17-20: global environment quality evaluation, referring to the whole school setting that students are daily experiencing.

4. Questions 21-26: self-awareness assessment of regulatory parameters in illumination design field, looking at students as future architects and designers.

5. Questions 27-35: lighting quality evaluation of 9 different school rooms, also assessed in relation to the kind of activity performed in it, through qualitative scoring from 1 (Min) to 5 (Max).

Later on, after assessing actual environment quality in daily-experienced surroundings, subjects are asked to evaluate a virtual representations of potential lighting systems. A virtual mock-up university classroom comparable in size, floor plan and windows layout to existing rooms belonging to the new wing of the School (building A), is projected through a monitor. In this mock-up, 8 different lighting systems and surface colours (different in light direction, temperature and colour choices) are applied through modelling software DiaLux Evo (summarized in Figure 1). The CRI is constant and equal to 84. All the pictures were drawn up taking values of average illuminance of 500 Lux, according to European legislation on lighting requirements for schools (EN 12464-1).

\begin{tabular}{|c|c|c|c|c|}
\hline Pictures & $\begin{array}{l}\text { Walls } \\
\text { colours / } \\
\text { reflectance }\end{array}$ & $\begin{array}{l}\text { Floor } \\
\text { colour/reflectance }\end{array}$ & Light source & $\begin{array}{l}\text { Light } \\
\text { colorimetric } \\
\text { parameters }\end{array}$ \\
\hline Pic 1 & $\begin{array}{l}\text { White, RGB: } \\
240,240,240 / \\
80 \%\end{array}$ & $\begin{array}{l}\text { Light grey, } \\
\text { RGB:190,187,182 } \\
/ 55 \%\end{array}$ & $\begin{array}{l}\text { Recessed } \\
\text { lay-in LED } \\
\text { lamps on } \\
\text { ceiling }\end{array}$ & $\begin{array}{l}\mathrm{CCT}=3259 \mathrm{~K} \\
\mathrm{CRI}=84\end{array}$ \\
\hline Pic 2 & $\begin{array}{l}\text { White, RGB: } \\
240,240,240 / \\
80 \%\end{array}$ & $\begin{array}{l}\text { Light grey, } \\
\text { RGB:190,187,182 } \\
/ 55 \%\end{array}$ & $\begin{array}{l}\text { Recessed } \\
\text { lay-in LED } \\
\text { lamps on } \\
\text { ceiling }\end{array}$ & $\begin{array}{l}\mathrm{CCT}=4033 \mathrm{~K} \\
\mathrm{CRI}=79\end{array}$ \\
\hline Pic 3 & $\begin{array}{l}\text { White, RGB: } \\
240,240,240 / \\
80 \%\end{array}$ & $\begin{array}{l}\text { Dark grey, RGB: } \\
146,145,141 / 31 \%\end{array}$ & $\begin{array}{l}\text { Recessed } \\
\text { lay-in LED } \\
\text { lamps on } \\
\text { ceiling }\end{array}$ & $\begin{array}{l}\text { CCT }=3259 \mathrm{~K} \\
\text { CRI }=84\end{array}$ \\
\hline Pic 4 & $\begin{array}{l}\text { White, RGB: } \\
240,240,240 / \\
80 \%\end{array}$ & $\begin{array}{l}\text { Dark grey, RGB: } \\
146,145,141 / 31 \%\end{array}$ & $\begin{array}{l}\text { Recessed } \\
\text { lay-in LED } \\
\text { lamps on } \\
\text { ceiling }\end{array}$ & $\begin{array}{l}\mathrm{CCT}=4033 \mathrm{~K} \\
\mathrm{CRI}=79\end{array}$ \\
\hline Pic 5 & $\begin{array}{l}\text { Blue, RGB: } \\
77,105,173 / \\
22 \%\end{array}$ & $\begin{array}{l}\text { Dark grey, RGB: } \\
146,145,141 / 31 \%\end{array}$ & $\begin{array}{l}\text { Recessed } \\
\text { lay-in LED } \\
\text { lamps on } \\
\text { ceiling }\end{array}$ & $\begin{array}{l}\mathrm{CCT}=3259 \mathrm{~K} \\
\mathrm{CRI}=84\end{array}$ \\
\hline Pic 6 & $\begin{array}{l}\text { Light } \\
\text { yellow, } \\
\text { RGB:255,24 } \\
5,227 / \\
83 \%\end{array}$ & $\begin{array}{l}\text { Light grey, } \\
\text { RGB:190,187,182 } \\
/ 55 \%\end{array}$ & $\begin{array}{l}\text { Recessed } \\
\text { lay-in LED } \\
\text { lamps on } \\
\text { ceiling }\end{array}$ & $\begin{array}{l}\text { CCT }=3259 \mathrm{~K} \\
\text { CRI }=84\end{array}$ \\
\hline Pic 7 & $\begin{array}{l}\text { Red, RGB: } \\
201,137,129 / \\
29 \%\end{array}$ & $\begin{array}{l}\text { Light grey, } \\
\text { RGB:190,187,182 } \\
/ 55 \%\end{array}$ & $\begin{array}{l}\text { Recessed } \\
\text { lay-in LED } \\
\text { lamps on } \\
\text { ceiling }\end{array}$ & $\begin{array}{l}\mathrm{CCT}=3259 \mathrm{~K} \\
\mathrm{CRI}=84\end{array}$ \\
\hline Pic 8 & $\begin{array}{l}\text { Green, RGB: } \\
160,166,115 / \\
70 \%\end{array}$ & $\begin{array}{l}\text { Light grey, } \\
\text { RGB:190,187,182 } \\
/ 55 \%\end{array}$ & $\begin{array}{l}\text { Recessed } \\
\text { lay-in LED } \\
\text { lamps on } \\
\text { ceiling }\end{array}$ & $\begin{array}{l}\mathrm{CCT}=3259 \mathrm{~K} \\
\mathrm{CRI}=84\end{array}$ \\
\hline
\end{tabular}

Figure 1: Overview table of lighting parameters and colour choices applied to rendering pictures

These conditions were selected with the aim to propose different combinations of light-coloured walls and floor, dark-coloured ones, primary-coloured painted walls, matched with both warm-light $(3000 \mathrm{~K})$ and cold-light $(4000 \mathrm{~K})$ solutions. The lighting system remains unchanged in all the pictures: LED ceiling lamps similar to existing ones in building A classrooms (Figure 2).

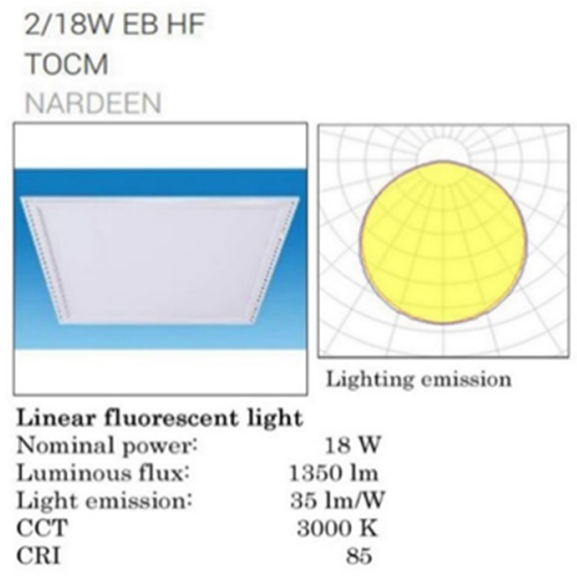

Figure 2: Data of lamps chosen for rendering pictures 
During this trial stage, students were asked to look at the 8 pictures inside a "test-box": the monitor is located inside a box closed on three sides and put on a work table, as shown in Figure 3. Participants look at the pictures inside the box: the casing shields the monitor from external light sources, so that visual perception is not altered. Participants were asked to rate from 1 (min) to 5 ( $\max$ ) the 8 pictures inside the test-box, according to their personal taste.
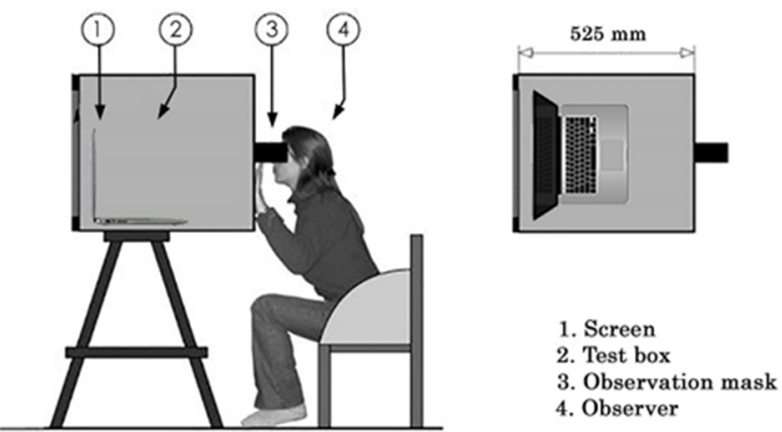

Figure 3: Clarification system of "test box" trial

Together with subjective analysis, on-site illuminance measurements were taken in order to link subject answers to current lighting and weather conditions, both factors influencing outcomes. Classrooms where students replied the questionnaire have been classified according to architectural and environmental features, including exposure, layout and windows surface amount (Figure 4). For each classroom, measurements points where students usually sit are indicated on floor plan, with related resulting values (Figure 5).

A luxmeter datalogger Delta Ohm HD2102.2 with the illuminance probe LP 471 PHOT was used to take illuminance measurements inside the classrooms. Furthermore, all lamps present in classrooms were collected and classified, with the aim to replicate ideal lighting conditions in virtual models.

A total amount of 7 experimentation days were carried out during a period between November 20th and December 18th, 2018. During the first six trial stages, 187 students were involved in the assessment questionnaire, spread over different learning courses at School. Among the students attending the trial, there were respectively 37 students enrolled at first grade, 131 from second grade and 19 from fourth grade. The last trial stage involved 52 students from 4th grade.

Illumination levels (Lux) have been reported in classrooms where trials were carried out, considering each room in two different situations: first with artificial lights on, and then with artificial lights off (only natural lighting). Results were summarised in charts (example in Figure 5), and ultimately, they shall be compared to each other in order to identify cases where both natural and artificial lighting levels are far away from regulatory requirements.

Illuminance measurements were taken during winter time (November-December) when there is a predominance of cloudy days, and when students are supposed to attend many classes inside school environment. During 6 days of trial, weather conditions didn't change much: mostly cloudy during daylight hours, with occasionally rainfall and temperature around $6^{\circ} \mathrm{C}$. Daylight in those days was pretty faint and tended to reduce significantly in early afternoon hours. These weather conditions often seem to not provide enough natural lighting inside learning environment, also due to windows' layout and exposure in most of the classrooms. That's why luxmeter measurements, taken on only-natural light condition, show significantly low values of lighting levels (as shown in Figure 4). Nevertheless, preliminary results show that natural lighting can't be adequately replaced by using only current artificial lighting systems (with particular reference to classroom 11). Luxmeter measurements shall be taken again during springtime (May), when students are still attending many classes, but weather conditions get better.

\begin{tabular}{|c|c|c|c|c|c|c|c|}
\hline $\begin{array}{l}\text { Classroom } \\
\text { number }\end{array}$ & $\begin{array}{l}\text { Building } \\
\mathrm{A} / \mathrm{B}\end{array}$ & $\begin{array}{l}\text { Windows } \\
\text { area / } \\
\text { floor area } \\
\text { (\% ratio) }\end{array}$ & \multicolumn{2}{|c|}{$\begin{array}{l}\text { Learning } \\
\text { activity }\end{array}$} & $\begin{array}{l}\mathbf{E} \min / \mathbf{E} \\
\text { average }\end{array}$ & Exposure & $\begin{array}{l}\text { Light } \\
\text { source }\end{array}$ \\
\hline 2 & B & $\begin{array}{l}75 \\
\mathrm{~m}^{2 / 161,9} \\
\mathrm{~m}^{2}(4 \%)\end{array}$ & \multicolumn{2}{|c|}{$\begin{array}{l}\text { Frontal } \\
\text { lectures } \\
\text { with } \\
\text { blackboard }\end{array}$} & $\begin{array}{l}66.7 \\
1 x / 15.67 \\
1 x\end{array}$ & East & $\begin{array}{l}5 \times 4 \\
\text { Fluorescent } \\
\text { lamps hang } \\
\text { on ceiling }\end{array}$ \\
\hline 11 & B & $\begin{array}{l}18,6 \\
m^{2 / 123,54} \\
m^{2}(15 \%)\end{array}$ & \multicolumn{2}{|c|}{$\begin{array}{l}\text { Frontal } \\
\text { lectures } \\
\text { with } \\
\text { projector }\end{array}$} & $\begin{array}{l}23.5 \mathrm{~lx} / \\
107.3 \mathrm{~lx}\end{array}$ & West & $\begin{array}{l}3 \times 8 \\
\text { Fluorescent } \\
\text { track } \\
\text { lighting } \\
\text { hang on } \\
\text { ceiling + } 6 \\
\text { fluorescent } \\
\text { wall lamps }\end{array}$ \\
\hline 18 & B & $\begin{array}{l}23 \mathrm{~m}^{2 / 177,2} \\
\mathrm{~m}^{2}(13 \%)\end{array}$ & \multicolumn{2}{|c|}{$\begin{array}{l}\text { Studio } \\
\text { class }\end{array}$} & $\begin{array}{l}4 \mathrm{~lx} / 139.5 \\
\mathrm{~lx}\end{array}$ & $\begin{array}{l}\text { North and } \\
\text { South }\end{array}$ & $\begin{array}{l}5 \times 7 \\
\text { Fluorescent } \\
\text { lamps hang } \\
\text { on ceiling }\end{array}$ \\
\hline 201 & A & $\begin{array}{l}31,2 \\
m^{2 / 118,7} \\
m^{2}(26 \%)\end{array}$ & \multicolumn{2}{|c|}{$\begin{array}{l}\text { Frontal } \\
\text { lectures } \\
\text { with } \\
\text { blackboard } \\
\text { and } \\
\text { projector }\end{array}$} & $\begin{array}{l}14 \\
1 \mathrm{l} / 122.4 \\
\mathrm{~lx}\end{array}$ & $\begin{array}{l}\text { East and } \\
\text { west }\end{array}$ & $\begin{array}{l}13 \times 2 \\
\text { Recessed } \\
\text { lay-in } \\
\text { compact } \\
\text { fluorescent } \\
\text { lamps on } \\
\text { ceiling }\end{array}$ \\
\hline 207 & A & $\begin{array}{l}9,88 \\
\mathrm{~m}^{2 / 147,2} \\
\mathrm{~m}^{2}(6 \%)\end{array}$ & \multicolumn{2}{|c|}{$\begin{array}{l}\text { Frontal } \\
\text { lectures } \\
\text { with } \\
\text { blackboard }\end{array}$} & $\begin{array}{l}54.4 \mathrm{~lx} / \\
214.4 \mathrm{xx}\end{array}$ & South & $\begin{array}{l}2 \times 7 \\
\text { Recessed } \\
\text { lay-in LED } \\
\text { lamps on } \\
\text { ceiling }\end{array}$ \\
\hline 402 & A & $\begin{array}{l}11,75 \\
\mathrm{~m}^{2 / 101,3} \\
\mathrm{~m}^{2}(11 \%)\end{array}$ & \multicolumn{2}{|c|}{$\begin{array}{l}\text { Frontal } \\
\text { lectures } \\
\text { and studio } \\
\text { class }\end{array}$} & $\begin{array}{l}12 \mathrm{l} x / 213.3 \\
\mathrm{~lx}\end{array}$ & East & $\begin{array}{l}2 \times 7 \\
\text { Recessed } \\
\text { lay-in LED } \\
\text { lamps on } \\
\text { ceiling }\end{array}$ \\
\hline \multicolumn{2}{|c|}{ Classroom number } & \multicolumn{2}{|c|}{ Building A/B } & \multicolumn{2}{|c|}{$\begin{array}{l}\text { E average value } \\
\text { (artificial } \\
\text { lighting) }\end{array}$} & \multicolumn{2}{|c|}{$\begin{array}{l}E \text { average } \\
\text { value (natural } \\
\text { lighting) }\end{array}$} \\
\hline \multicolumn{2}{|l|}{2} & \multicolumn{2}{|l|}{ B } & \multicolumn{2}{|c|}{$121.25 \mathrm{~lx}$} & \multicolumn{2}{|c|}{$79.77 \mathrm{~lx}$} \\
\hline \multicolumn{2}{|l|}{11} & \multicolumn{2}{|l|}{ B } & \multicolumn{2}{|c|}{$37.3 \mathrm{~lx}$} & \multicolumn{2}{|c|}{$116.1 \mathrm{~lx}$} \\
\hline \multicolumn{2}{|l|}{18} & \multicolumn{2}{|l|}{ B } & \multicolumn{2}{|c|}{$453.5 \mathrm{~lx}$} & \multicolumn{2}{|c|}{$78.67 \mathrm{~lx}$} \\
\hline \multicolumn{2}{|l|}{201} & \multicolumn{2}{|l|}{$\mathrm{A}$} & \multicolumn{2}{|c|}{$234 \mathrm{~lx}$} & \multicolumn{2}{|c|}{$46.72 \mathrm{~lx}$} \\
\hline \multicolumn{2}{|l|}{207} & \multicolumn{2}{|l|}{ A } & \multicolumn{2}{|c|}{$318.8 \mathrm{~lx}$} & \multicolumn{2}{|c|}{$79.66 \mathrm{~lx}$} \\
\hline 402 & & A & & $480 \mathrm{l}$ & & 43.51 & \\
\hline
\end{tabular}

Figure 4: Features of classrooms where trial was carried out 


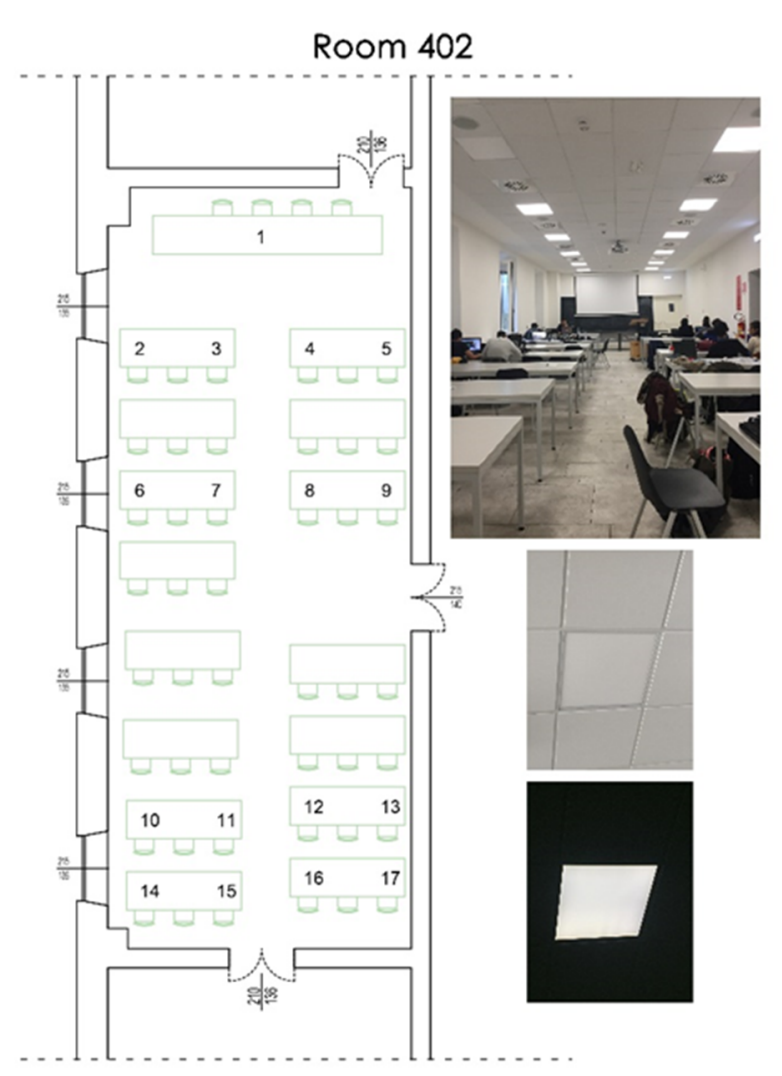

\begin{tabular}{|r|c|c|} 
Seats & $\begin{array}{c}\text { Lux values reported at } \\
14: 30 \text { p.m. on } 11.29 .18- \\
\text { Lights on, open windows }\end{array}$ & $\begin{array}{c}\text { Lux values reported at } \\
14: 45 \text { p.m. on } 11.29 .18- \\
\text { Lights off, open windows }\end{array}$ \\
\hline 1 & $560 \mathrm{~lx}$ & $56 \mathrm{~lx}$ \\
\hline 2 & $490 \mathrm{~lx}$ & $13 \mathrm{~lx}$ \\
\hline 3 & $574 \mathrm{~lx}$ & $16 \mathrm{~lx}$ \\
\hline 4 & $580 \mathrm{~lx}$ & $12 \mathrm{~lx}$ \\
\hline 5 & $478 \mathrm{~lx}$ & $12 \mathrm{~lx}$ \\
\hline 6 & $854 \mathrm{~lx}$ & $426 \mathrm{~lx}$ \\
\hline 7 & $524 \mathrm{~lx}$ & $171 \mathrm{~lx}$ \\
\hline 8 & $515 \mathrm{~lx}$ & $25 \mathrm{~lx}$ \\
\hline 9 & $496 \mathrm{~lx}$ & $23 \mathrm{~lx}$ \\
\hline 10 & $854 \mathrm{~lx}$ & $456 \mathrm{~lx}$ \\
\hline 11 & $502 \mathrm{~lx}$ & $146 \mathrm{~lx}$ \\
\hline 12 & $207 \mathrm{~lx}$ & $22 \mathrm{~lx}$ \\
\hline 13 & $300 \mathrm{~lx}$ & $18 \mathrm{~lx}$ \\
\hline 14 & $407 \mathrm{~lx}$ & $52 \mathrm{~lx}$ \\
\hline 15 & $430 \mathrm{~lx}$ & $24 \mathrm{~lx}$ \\
\hline 16 & $465 \mathrm{~lx}$ & $19 \mathrm{~lx}$ \\
\hline 17 & $367 \mathrm{~lx}$ & $26 \mathrm{~lx}$ \\
\hline
\end{tabular}

Figure 5: From above to the left: Floor plan and pictures of a classroom 402 inside building A, pictures of the classroom and of existing lamps, and table with illuminance levels measured in it (first with lights on and then with lights off)

\section{Results}

Differences emerge between students attending building A and the ones studying in building B: first ones mostly gave positive appraisals of their school environment, while second ones generally show dissatisfaction with it. (Figure 6).

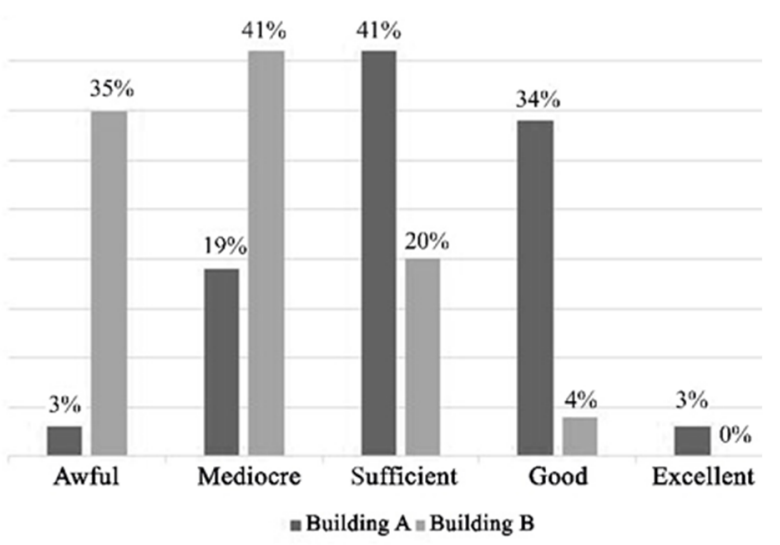

Figure 6 : Assessment of school environment quality related to two different School seats

The difference between the two buildings does not depend exclusively on the age of the building, and on the fact that a wing of building $\mathrm{A}$ - where trial was carried out - was recently refurbished. These two seats highly differ from each other in classrooms layouts, windows sized and distribution, and furnishing distribution inside classrooms. Renovated classes in building A are generally characterised by rectangular layouts, uniform desks distribution, and several and wide windows on a whole wall or on two opposite walls. Otherwise, there are many different spaces in building $\mathrm{B}$, and inside some of them windows are only a few, or too little to light up the whole space, or badly exposed to light, or not located in ideal positions (behind student's backs as in classroom 11).

Therefore, during subjective analysis stage, it was decided to shape the virtual mock-up classroom with reference to architectural features of building A's refurbished classrooms: the virtual model shares with existing rooms the rectangular floor plan, windows size and distribution all over a single wall, ceiling height, and number, type and layout of ceiling lamps.

There's another important finding related to how much time architecture students spend working on a computer for school projects: $100 \%$ of 4th grade students declare an everyday use of laptop, and $63 \%$ of them use it for more than 6 hours a day. Only students from 1st year say they don't need to use it very much: $80 \%$ of them use a laptop only 2-3 hours a day, and half of them don't even use it every day. This degree curriculum requires daily and long laptop activity, mostly inside school spaces, and it becomes more and more essential for students every year (Figure 7). 


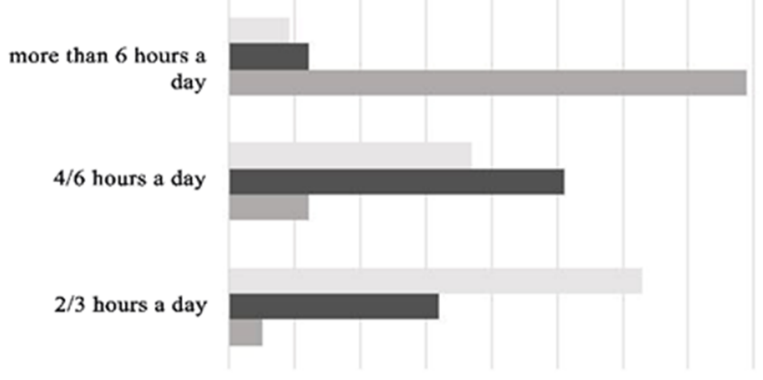

$\begin{array}{lllllllll}0 \% & 10 \% & 20 \% & 30 \% & 40 \% & 50 \% & 60 \% & 70 \% & 80 \%\end{array}$ 4 th grade students $=2$ nd grade students $\equiv 1$ st grade students

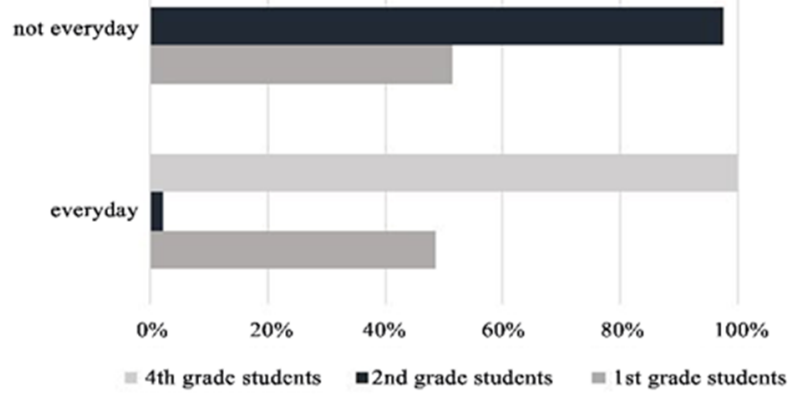

Figure 7 : Replies to question: "how much time do you spend using a computer?"

Over-exposure to back-lighting screen could be related to visual disorders, which affect mainly older students, only $20 \%$ of 4 th grade students don't suffer for any visual disease, compared to $30 \%$ of 1 st grade students. Among most common diseases, $47 \%$ of respondents suffer for myopia, and $29 \%$ suffer for astigmatism; students from 4th year widely suffer also for headache and visual fatigue (Figure 8).

\section{Visual disorders}

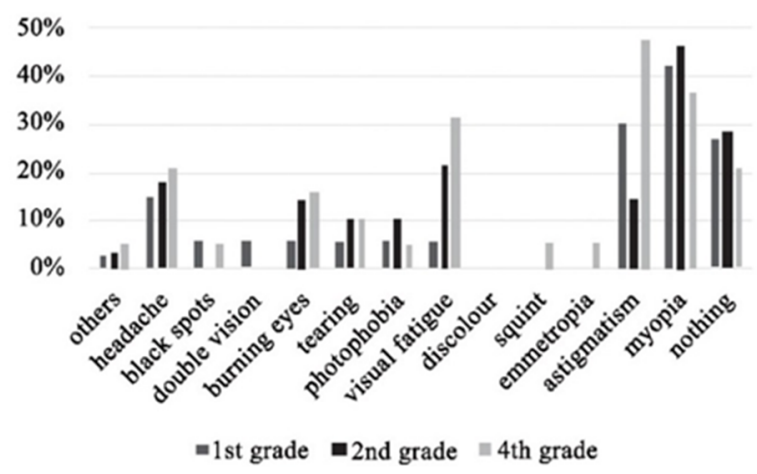

Figure 8: Visual disorders penetration rates

Then respondents were asked to assess lighting quality in classrooms related to educational activities carried out in it, including frontal lectures (often requiring a projector), drawing studio classes, design classes (making a full use of computer) and technical work like building handmade scale models. The results of questionnaire responses show that no classroom was scored with a top grade for lighting environment; moreover, older classrooms in building B got the lower scores.
The gap between the two school seats is notably pronounced relating to technical activities such as drawing classes, building A environment are deemed appropriate for such classes, while building B classrooms don't satisfy students at all (Figure 9).

Overall, students claim that they have sufficient awareness of good lighting requirements, although only $5,5 \%$ of them feels to be well prepared (despite basic lighting teaching is provided for in the curriculum) (Figure 10).

\section{Scores referred to building A}

\begin{tabular}{|l|l|l|l|l|l|}
\hline & Awful & Mediocre & Sufficient & Good & Excellent \\
\hline $\begin{array}{l}\text { Hand- } \\
\text { made } \\
\text { modelling }\end{array}$ & $6,15 \%$ & $29,23 \%$ & $47,69 \%$ & $16,92 \%$ & $0 \%$ \\
\hline $\begin{array}{l}\text { Technical } \\
\text { activities }\end{array}$ & $10,71 \%$ & $17,86 \%$ & $50 \%$ & $17,86 \%$ & $3,57 \%$ \\
\hline $\begin{array}{l}\text { Studio } \\
\text { classes }\end{array}$ & $0 \%$ & $14,29 \%$ & $28,57 \%$ & $42,86 \%$ & $14,29 \%$ \\
\hline $\begin{array}{l}\text { Formal } \\
\text { lectures }\end{array}$ & $0 \%$ & $7,14 \%$ & $42,86 \%$ & $39,29 \%$ & $10,71 \%$ \\
\hline
\end{tabular}

Scores referred to building B

\begin{tabular}{|l|l|l|l|l|l|}
\hline & Awful & Mediocre & Sufficient & Good & Excellent \\
\hline $\begin{array}{l}\text { Hand- } \\
\text { made } \\
\text { modelling }\end{array}$ & $6,15 \%$ & $19,23 \%$ & $47,69 \%$ & $16,92 \%$ & $0 \%$ \\
\hline $\begin{array}{l}\text { Technical } \\
\text { activities }\end{array}$ & $26,32 \%$ & $47,37 \%$ & $21.05 \%$ & $0 \%$ & $0 \%$ \\
\hline $\begin{array}{l}\text { Studio } \\
\text { classes }\end{array}$ & $26,32 \%$ & $52,63 \%$ & $21,05 \%$ & $0 \%$ & $0 \%$ \\
\hline $\begin{array}{l}\text { Formal } \\
\text { lectures }\end{array}$ & $10,53 \%$ & $63,16 \%$ & $26,32 \%$ & $0 \%$ & $0 \%$ \\
\hline
\end{tabular}

Figure 9: Assessment of lighting quality related to activities carried out in classrooms

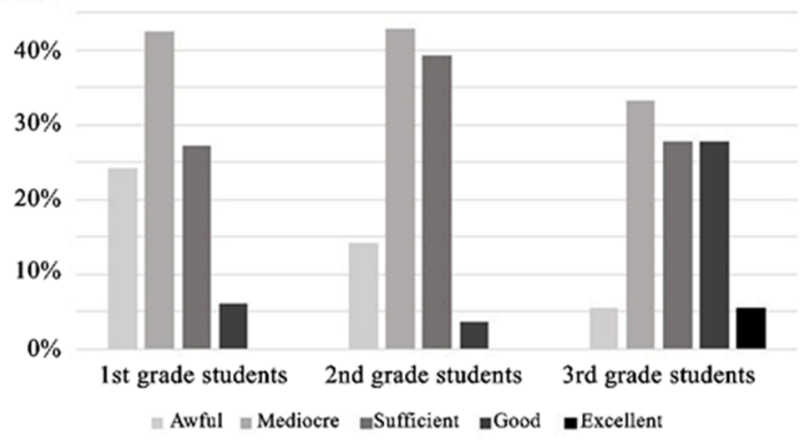

Figure 10: Self-awareness assessment of regulatory parameters in illumination design field

This fact may be connected to another two interesting results: architecture students give much more value to natural lighting design than to artificial lighting design, and this is particularly true for older students; high levels of daylight are welcomed despite students using laptop for a long time (see Figure 7).

Seventh and final test was conducted on 18th of December, involving 52 students, 25 males and 27 females. Participants were asked to rate from 1 ( $\mathrm{min}$ ) to 5 (max) the 8 pictures inside the test-box previously described (Figure 3). The values have been collected and averaged with reference to each single proposed solution (Figure 11).There were no significant differences between scores awarded by female students and ones awarded by males (Figure 12). 
It was found that pictures in which the classroom is painted with bright colours and illuminated with warm light (pictures 3 and 6, Figure 13) are preferred over ones in which a cold light is applied. Solution that had the lower score is picture number 2 (Figure 14), which characteristics are reported in Figure 1.

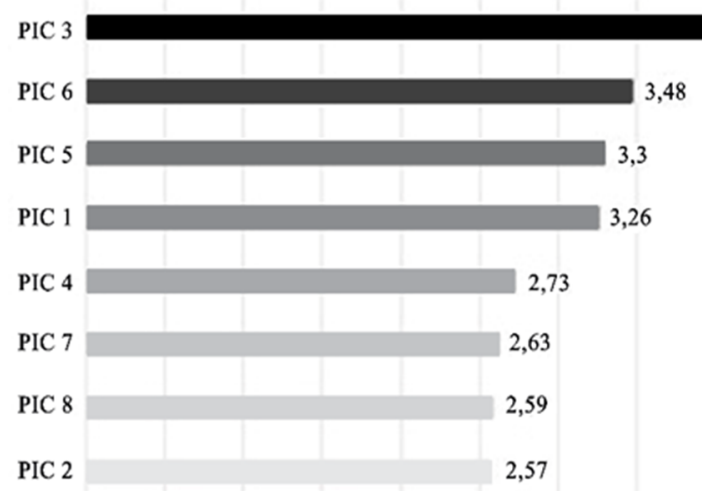

Figure 11: Average of the scores given to single pictures (range from 1 to 5)

\section{GEMALES MALES}

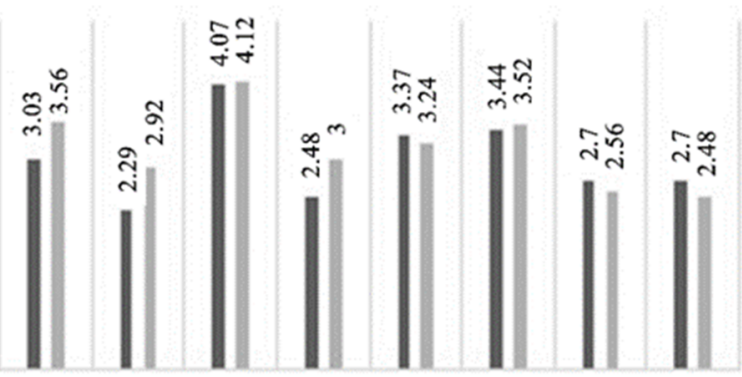

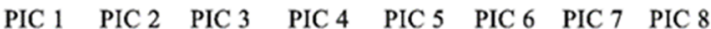

Figure 12: Average of the scores given related to gender of the evaluators; values from 1 ( $\mathrm{min}$ ) to 5 ( $\mathrm{max}$ )
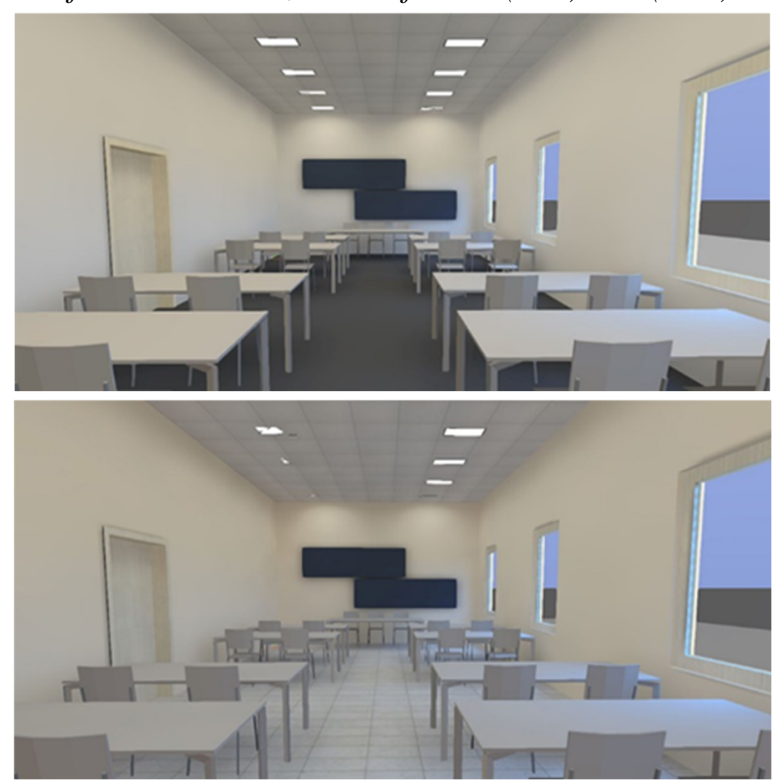

Figure 13: Pictures 3(top) and 6 (bottom) rated with higher scores

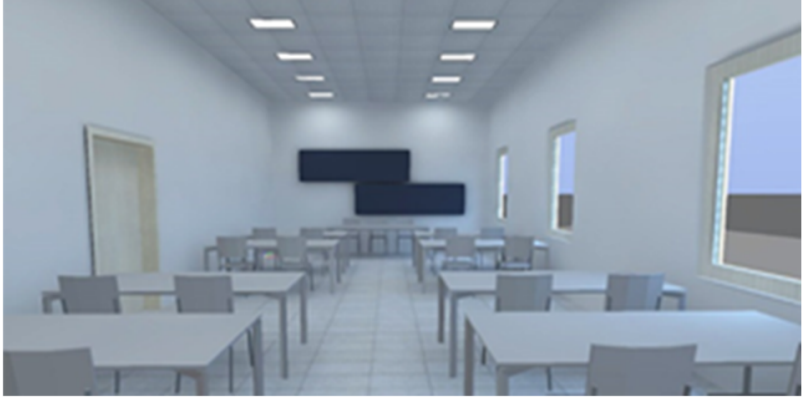

Figure 14: Picture 2 rated with lower scores

In order to verify whether there is a match between classroom walls colours and students' preferences, participants were invited to state their favourite 5 colours on World Colour Survey diagram (Kay et al., 2015). We can conclude from outcomes that most of the students give preference to following colours on WCS diagram:

B-5 (light pink), C-10 (light yellow), E-5 (orange), G-16 (green-blue), C-23 (light blue) (Figure 15).

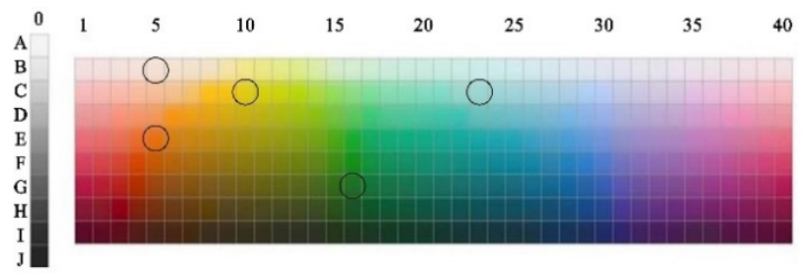

Figure 15: Favourite colours selected on WCS diagram

\section{Conclusion}

Involving students in the trial and asking them to express their subjective perception of school environment proved to be extremely important. This way, it has been possible to investigate users' feelings, and reach many conclusions: lighting solutions adopted inside Architecture School environment don't always fulfil students' needs and tastes. As previously mentioned, Architecture degree requires an all-day-long stay inside school environment: and as the school years go forward, students are supposed to spend more and more time inside school building, often even during night-opening. Artificial lighting in many classrooms, as emerges from the data in Figure 4, is not always capable to adequately make up for natural light absence. Therefore, according to several researches undertaken on working environment lighting, it would be advisable to think about a dynamic and variable-during-the-day lighting system, so that it can be closer to light-dark cycles and can properly enhance circadian rhythms. This way, light becomes a means of implementation of biological effects of light.

It might be important to consider the differences emerged between the answers given by the students enrolled in the last years (4th year) and those given by the students of the first years (1st and 2nd).

Elder students, in addition to spending longer times inside school, are more exposed to laptop back-lighting screens, as they need to study and work on their computers much more than their younger colleagues do. Besides, outcomes show that visual disorders and 
worsening of vision are more widespread within elder students. Therefore, in line with other studies, the following topic will be further investigated: real adequacy of existing lighting system for students who are regularly exposed to screen light, and how much it is related to worsening visual disorders. A bad quality of light, as many researches highlight, not only leads to visual fatigue, but it also has adverse repercussions on emotive issues, causing lack of attention and students' performance. That's why it's important to consider, in learning environments as well, important parameters already adopted in computer workstations and other spaces within the offices, such as illumination, luminance distribution, glare (UGR), and colour rendering index (CRI).

With regard to users' assessments, refurbished building environment is much more highly evaluated than older building one. Trial results point out critical issues, especially according to students who attend the building where there's a fewer natural lighting. Furthermore, School of Architecture environments require different lighting specifications depending on varying visual tasks, which can change during the same day according to teaching activities carried out (like going from a studio class to a frontal lecture). This suggests that it is necessary to have the chance to adjust intensity and quality of light, changing for instance lamps colour temperature. That's why a lighting system capable of adapting to changing needing is recommended.

In conclusion, students' assessment regarding the virtual classroom pictures (second trial stage) shows how all respondents' tastes share the same preferences, with no meaningful distinction based on people gender or age: users would rather attend classrooms characterized by light and bright tones, not strongly coloured, and they feel better with a diffused and warm lighting. This trial stage has been significantly useful in order to defining lighting and environmental models that meet the subjects' needs; students had the chance to picture the most suitable environment for their learning activities, accounting this degree's abovementioned characteristics.

Users' predilections about lighting temperature and surfaces colours should be taken into account while developing a good design (Marty et al., 2003). Artificial lighting design should be considered as a significant design factor, especially in educational environment. The success of the project should be related to physical and psychological conditions of users, and not only to the fulfilment of limit values given by standards.

\section{References}

Baron, R. A. and Rea, M. S. (1991), Lighting to Soothe the Mood. In Lighting Design and Application, pp.30-32.

Berson, D.M. (2002), Melanopsin and phototransduction by retinal ganglion cells. Final Report. The Fifth International LRO Lighting Research Symposium, "Light and Human Health", November 3-5.
Berson, D.M. (2002), Strange vision: ganglion cells as circadian photoreceptors. Trends Neuroscience 2003; Jun; 26(6): pp.314-20.

Berson, D.M., Dunn, F.A., Motoharu T. (2002), Phototransduction by retinal ganglion cells that set the circadian clock. Science. 2002; 295: pp. 1070-73.

Boyce, P.R. (2004), Lighting research for interiors: the beginning of the end or the end of the beginning, Light. Res. Technol., 36, pp. 283-294.

Boyce, P.R. (2013), Lighting quality for all, CISBE SLL Int. Light. Conf., Dublin, pp. 1-5.

Brainard, G.C., Rollag M.D., Hanifin J.P. (1997), Photic regulation of melatonin in humans: ocular and neural signal transduction, J Biol Rhythms;12(6): pp. 53746.

Brainard, G.C., Hanifin. J.P, Rollag M.D., Greeson J., Byrne B., Glickman G., et al. (2001), Human melatonin regulation is not mediated by the three cone photopic visual system., J Clin Endocrinol Metab; pp. 433-466.

Castilla N., Llinares C., Bravo J.M., Blanca-Giméneza V. (2017), Subjective assestment of university classroom environment, Building and Environment, volume 122, pp. 72-81.

Castilla N., Llinaresb C., Bisegnac F., Blanca-Giméneza V. (2018), Emotional evaluation of lighting in university classrooms: A preliminary study, published on Frontiers of Architectural Research, volume 7, Issue 4, Dcember 2018, pp. 600-609.

European Committee for Standardiztion (2011), Light and lighting - Lighting of work places - Part 1: Indoor work places (EN 12464-1).

Flynn J.E. (1992), Interim Study of Procedures for Investigating the Effect of Light on Impression and Behavior. Selected Paper on Archirectural Lighting. Ed. Mark Rea. SPIE Optical Engineering Press, Washington.

Kay, P. and Cook, R.S. (2015), World Color Survey. Encyclopedia of Color Science and Technology DOI 10.1007/978-3-642-27851-8_113-10.

Khademagha P. , Aries M.B.C., Rosemann A.L.P., van Loenen E.J. (2016), Implementing non-imageforming effects of light in the built environment: a review on what we need, Build. Environ., 108, pp. 263-272, 10.1016/j.buildenv.2016.08.035.

Králiková R., Piňosová M., Hricová B. (2016), Lighting quality and its effects on productivity and human healts, Int. J. Interdiscip. Theory Pract, 10.

Kruisselbrink T., Dangol R., Rosemann A. (2018), Photometric measurements of lighting quality: an overview, Building and Environment, Volume 138, 15 June 2018, pp. 42-52.

Marty C., Fontoynont M., Christoffersen J., Dubois MC., Wienold J., Osterhaus W. (2003) User assessment 
of visual comfort: review of existing methods, Ingélux (France) with Danish Building Research Institute (SBi, Denmark) and Fraunhofer Institute for Solar Energy Systems (ISE, Germany), DOI: 10.13140/RG.2.1.4803.7843.

Ödemis K., Yener C., Camgöz N. (2011), Effects of Different Lighting Types on Visual Performance, Published online: 11 Oct 2011, https://doi.org/10.1080/00038628.2000.9697535, pp. 295-301.

Pechacek, C. (2008), Space, light, and time: prospective analysis of Circadian illumination for health-based daylighting with applications to healthcare architecture, Massachusetts Institute of Technology, Dept. of Architecture.

Shahrom, F. (2015), Progetto green school: valutazione del comfort visivo negli edifici scolastici attraverso un'analisi oggettiva e soggettiva: il caso studio
dell'Istituto Maxwell di Nichelino. Politecnico di Torino, Corso di Laurea magistrale in Architettura Costruzione Città.

Van Bomme W., Van den Beld G.J. (2004), Lighting for work: A review of visual and biological effects, Lighting Research and Technology 36(4):255-269, DOI: 10.1191/1365782804li122oa.

Veitch J.A. (2000), Lighting guidelines from lighting quality research, CIBSE/ILE Light. 2000 Conf., York, $U K(2000)$.

Veitch J.A. (2001) Psychological processes influencing lighting quality, J. Illum. Eng. Soc., pp. 30.

Veitch J.A. (2013), Determinants of lighting quality I: State of the science, Published online: 19 Sep 2013, https://www.tandfonline.com/doi/abs/10.1080/00994 480.1998.10748215, pp. 92-106.

DIAlux EVO manual Software vers. 8.1 (2016) 